\title{
Value Relevance of Embedded Value and IFRS 4 Insurance Contracts
}

\author{
Rebecca Chung-Fern Wu and Audrey Wen-Hsin Hsu \\ Department of Accounting, National Taiwan University, Room 1001, 85 Sec. 4 Roosevelt Road, Taipei, \\ Taiwan 106, Taiwan. \\ E-mail: rcfwu@ntu.edu.tw
}

In light of the recent exodus of foreign insurers from Taiwan and the local insurers' outcries against the International Financial Reporting Standard (IFRS) 4 Insurance Contracts, we examine the value relevance of financial statements for life insurance firms, with particular interests to the embedded value (EV) disclosure. We find that the EV of equity has an incremental information role for book value of equity, which indicates that the accounting mismatching problem in the insurance industry creates a demand for fair value accounting. The fair value of liabilities under IFRS 4 Phase 2 has been disputed globally by accountants, actuaries, academia and regulators. The EV model is a concept approaching the fair value model. The research findings provide important empirical evidences supporting the fair value concept of IFRS 4.

The Geneva Papers (2011) 36, 283-303. doi:10.1057/gpp.2011.5

Keywords: embedded value; IFRS 4; insurance contracts; life insurance accounting

\section{Introduction}

In light of the recent disposals of Taiwanese operations by foreign insurance firms, the adoption of International Financial Reporting Standard (IFRS) No. 4 Phase I (equivalent to ROC generally accepted accounting principles (GAAP) No. 40) in Taiwan from 2011 is expected to create challenges for insurers in Taiwan. ${ }^{1}$ Fitch Ratings have indicated that the recent exits of foreign life insurers are mainly driven by the stricter requirements of IFRS 4 and European solvency standards rather than Taiwan local insurance regulations. ${ }^{2}$ In October 2008, ING Group sold its Taiwanese life insurance business to Fubon Financial Holding Co. Life operations in Taiwan have long been a risk burden for ING Group because of its reserve inadequacy. The inadequacy results from a material exposure to a sustained low interest rate environment in Taiwan, along with a guaranteed long-term interest rate of 6-8 per cent embedded in the life and health policies sold before 2001. ING has over time strengthened reserves by $€ 828$ million for this exposure and increased the internal capital allocation for the business. At the end of 2007, when ING Group tested for the adequacy of insurance liability under IFRS 4 and European solvency regulations by evaluating insurance liabilities on current best estimated actuarial assumptions plus a

\footnotetext{
${ }^{1}$ Please see Lee (2009) and Hsu (2010).

${ }^{2}$ Please see Yang (2009).
} 
risk margin, the legacy products of guaranteed long-term interest rate together with the future anticipated premiums on these Taiwan policies contributes to a level of reserve inadequacy by $€ 1.5$ billion. The amount accounts for about 24 per cent of insurance revenue in Asia Pacific. ${ }^{3}$ In addition to ING, many foreign insurers (i.e., Prudential Life, Metlife, Aegon, and possibly AIG) also chose to exit from Taiwan during the economic breakdown because of the same capital inadequacy challenges. 4

In this study, we test the value relevance of embedded value (EV). Traditional insurance accounting in Taiwan generates distorted value-added signals as it ignores the future potential performance from existing contracts. ${ }^{5}$ Specifically, it only focuses on the realisation of in-force business profits and does not allow insurers to recognise expected future profits. For a typical life insurance contract, there is a peak of customer acquisition cash outflow at the point of sale, followed by a steady level of cash inflows, and then followed by a large cash outflow at termination (i.e., death or maturity of the policy). As profits are not recognised until the periods when premiums are received and the acquisition costs of insurance contracts are immediately expensed in the first year when they are incurred, the timing differences between revenue and expense recognition causes a "mismatch" between economic profits and accounting profits for each reporting period. Thus, at the early stage, companies with more new businesses may suffer larger losses, and the value of companies can be underestimated. Because of potential problems in traditional insurance accounting, more and more lifeinsurance companies are using the EV model to evaluate performance, as many believe that value-added accounting can help management deploy capital more appropriately and direct the firm away from products that are destroying value and move capitals towards those that are adding value. ${ }^{6} \mathrm{EV}$ is equal to the sum of the value of the in-force business and the shareholders' net worth, adjusted for the cost of holding capital. EV reporting can aid in communication with stakeholders by improving the transparency of financial performance. Analysts also prefer EV to conventional accounting measures.

We test whether EV (i.e., additional retained profits on an EV basis; ARP) has an incremental role for stock valuation, in addition to the element that has been taken into account in the books (BV) using Ohlson valuation model. Our empirical data is based on a sample of Taiwan insurance companies during 2005-2008. We also examine the value relevance of book value and ARP for European insurers to provide implications for recent EU insurers' exodus from Taiwan, and to compare its difference from Taiwan.

We find that EV is value relevant, and ARP plays an important role in valuation of both Taiwan and EU insurers. We also find that the value relevance of

\footnotetext{
${ }^{3}$ See ING's Annual report in 2007 and Chen and Chang (2009).

${ }^{4}$ Prudential Plc., the second largest insurer in the EU, can boost its capital surplus by 1.13 million dollars after transferring its Taiwanese sales force and 94 per cent of its liabilities on the island to China's biggest insurer for a nominal sum of NT \$1.

${ }^{5}$ Please see Chien (2005); Lee (2009); and Hsu (2010).

${ }^{6}$ See CFO Forum (2004, 2005, 2008); Campbell (2002); and Duverne and Le Douit (2007) for the increasing use of embedded value model. Graham et al. (2003) and Klumpes (2005) provide the reasons.
} 
Taiwan insurers' equity book value is much lower than that of EU insurers. This suggests that there is a cross-country regulatory imparity in addressing the associated risk of negative interest spreads. Of greatest impact on life insurers is IFRS 4, an accounting standard issued by the International Accounting Standards Board (IASB) to improve public disclosures of insurance contracts. In 2004, IASB announced IFRS 4 Phase I, and plans to issue Phase II of IFRS 4 in 2011. Although insurance companies in Taiwan have not been required to adopt Phase I of IFRS4 until 2011, European companies needed to comply with the standard starting from 2005. Our results suggest that different accounting requirements can create an unlevelled playing field that allows local insurers to gamble on the European policies, aiming to grab more market share.

These results contribute to the literature on fair value accounting. We provide early evidence of the value relevance of EV disclosures. Our contributions can include two parts. First, as IFRS 4 Phase 2 requires fair value measurement of all contractual cash flows on assets and liabilities, many insurance companies are concerned with serious capital inadequacy. The EV model is a concept approaching the fair value model, and our study can provide important evidence supporting IFRS 4. Second, our evidence provides implications to regulators that levelling a playing field similar to other countries is extremely important to avoid the arbitrage of the regulation. Since highinterest rates guaranteed products are prevalent in Taiwan and the insurance reserve provisioning is based on initial investment return assumption (i.e., the current interest rates need not be reflected), it is difficult for investors to depict the full picture solely based on financial reports.

The paper is organised as follows. The next section introduces the EV model and Taiwan insurance accounting, followed by the hypothesis and research design. We report empirical results in the penultimate section. The conclusion and discussion are provided at the end of the paper.

\section{EV and insurance accounting}

\section{Embedded value}

While prior studies ${ }^{7}$ have proposed many valuation approaches for insurers' assets and liabilities, EV methodologies are of particular interests as they are traditionally used in many countries such as U.K. and Australian actuaries. EV is recognised as the present value of the future cash flows from existing insurance contracts that will be distributable to shareholders. Some insurers' financial reports' users, especially analysts, consider EV information to be more relevant than accounting-based information. EV can be defined in two ways:

$$
\begin{aligned}
E V_{i t} & =A N A V_{i t}+V I F_{i t}-C O C_{i t} \\
& =B V_{i t}+A R P_{i t}
\end{aligned}
$$

\footnotetext{
${ }^{7}$ Please see Reitano (1997); Babbel and Stricker (1987); and Babbel and Merrill (1998, 1999).
} 
On the one hand, as described by the CFO Forum, ${ }^{8}$ EV can be defined as the sum of adjusted net worth $\left(A N A V_{i t}\right)$ and the value of the in-force covered business $\left(V I F_{i t}\right)$ minus the cost of holding required capital $\left(C O C_{i t}\right)$. Adjusted net worth $\left(A N A V_{i t}\right)$ equals to the free surplus and the required capital. $A N A V_{i t}$ represents the element of EV that is most closely linked to statutory GAAP equity (i.e., book value of shareholders' equity (BV)).

The value of $V I F_{i t}$ is defined as the present value of future after-tax statutory book profits expected to arise from the in-force business, including new business written in the reporting period. In the EV model, debate is rampant among actuaries over the appropriate method to incorporate risk into the liability valuation. ${ }^{9}$ Under the EV approach, risk is incorporated by the required profit components or risk capital charges that must be added to the liability cash flows. However, the IASB's view on a fair value measurement basis remains highly contentious. Prior studies ${ }^{10}$ argue that liabilities are affected by three sources of uncertainty: actuarial risks, market risks and firm-specific risks. But these risks can vary with different value sources. For instance, EV might arise from three major sources: franchise value, net tangible value and put option value; and insolvency risk is negatively related with franchise value but positively related with put option value. ${ }^{9}$ The value of put option can increase as the insurers' insolvency risk increases.

On the other hand, embedded value $\left(E V_{i t}\right)$ can be decomposed into two parts: book value of shareholders' funds under statutory GAAP basis $\left(B V_{i t}\right)$ and additional retained profit on an $\mathrm{EV}$ basis $\left(A R P_{i t}\right) . B V_{i t}$ refers to the element that has been recognised in the books and ARP relates to the portion that has not been accounted for. Many insurers in the EU provide a reconciliation table that links statutory IFRS basis shareholders' funds to EV-basis shareholders' funds. Table 1 illustrates the reconciliation of movements in shareholders' funds by Prudential, 2005 EV report. Table 1 links "statutory IFRS basis shareholders' funds (BV)" to "EV-basis shareholders' funds (EV)" with the difference being described as "Additional retained profit on an EEV basis (ARP)". It also shows that EV consists of (1) free surplus and required capital (ANAF), (2) value of in-force business (VIF) and (3) cost of capital and timing value of guarantees (COC).

In summary, a detailed EV schedule provides useful insight into the sources of profitability. The relevance of EV information is greatly improved by linking EV with IFRS as clearly as possible. One main reason is that there is a discrepancy in measurement of insurance assets and liabilities. While most of the insurance assets are marked to market according to International Accounting Standard 39 (IAS 39), IFRS 4 Phase 1 still failed to use fair value to measure insurance liabilities. Measuring the fair value of liabilities has been disputed globally by accountants, actuaries, researchers and regulators. Comments request period for IFRS 4 Phase 2 Exposure Draft by IASB ended on 30 November 2010.

\footnotetext{
${ }^{8}$ CFO Forum $(2004,2005)$.

${ }^{9}$ Please see Babbel and Merrill (1998); Babbel and Stricker (1987); and Staking and Babbel (1995).

${ }^{10}$ For example Babbel and Merrill (1998).
} 
Table 1 Reconciliation of movement in shareholders' funds

\begin{tabular}{|c|c|c|c|c|c|c|}
\hline \multirow{2}{*}{$\begin{array}{l}\text { EV basis shareholder's funds } \\
\text { at } 31 \text { Dec. } 2005\end{array}$} & \multicolumn{6}{|c|}{ Long-term business operations } \\
\hline & $\begin{array}{c}U . K . \text { insurance } \\
\text { operations } \\
£ m\end{array}$ & $\begin{array}{l}\text { U.S. } \\
\text { operations } \\
\quad £ m\end{array}$ & $\begin{array}{l}\text { Asian } \\
\text { operations } \\
£ m\end{array}$ & $\begin{array}{c}\text { Total long-term } \\
\text { business } \\
\text { operations } £ m\end{array}$ & $\begin{array}{c}\text { Other } \\
\text { operations } \\
£ m\end{array}$ & $\begin{array}{c}\text { Group } \\
\text { total } \\
£ m\end{array}$ \\
\hline \multicolumn{7}{|l|}{ Analysed as: } \\
\hline $\begin{array}{l}\text { Statutory IFRS basis } \\
\text { shareholders' funds }\end{array}$ & 1,141 & 2,899 & 1,034 & 5,074 & 120 & 5,194 \\
\hline $\begin{array}{l}\text { Additional retained profit } \\
\text { on an EV basis }\end{array}$ & 3,991 & 499 & 954 & 5,394 & $(287)$ & 5,107 \\
\hline $\begin{array}{l}\text { EV basis shareholders' } \\
\text { funds at } 31 \text { Dec. } 2005\end{array}$ & 5,132 & 3,348 & 1,988 & 10,468 & $(167)$ & 10,301 \\
\hline \multicolumn{7}{|l|}{ Comprising } \\
\hline Free surplus & 148 & 899 & $(212)$ & 835 & & \\
\hline Required capital & 710 & 1,198 & 974 & 2,882 & & \\
\hline \multicolumn{7}{|l|}{$\begin{array}{l}\text { Value of in-force business } \\
\text { before deduction of }\end{array}$} \\
\hline $\begin{array}{l}\text { Cost of capital and of } \\
\text { guarantees }\end{array}$ & 4,529 & 1,511 & 1,771 & 7,811 & & \\
\hline Cost of capital & $(192)$ & $(117)$ & $(539)$ & $(848)$ & & \\
\hline \multirow{2}{*}{$\begin{array}{l}\text { Cost of time value of } \\
\text { guarantees }\end{array}$} & $(63)$ & $(143)$ & (6) & $(212)$ & & \\
\hline & 5,132 & 3,348 & 1,988 & 10,468 & & \\
\hline
\end{tabular}

Note: IFRS equity vs. European embedded value (EV)_Prudential, 2005 EV report, Note 14, page 224.

In addition to EV, other value-based indicators such as Appraisal Value (AV), ${ }^{11}$ Market Value (MV) and Shareholder Value (SV) are used to appraise life insurance companies' operating performance. AV includes the estimated value of new businesses in the future (i.e., goodwill), but EV does not. AV and MV are influenced by not only companies' internal factors but also market and consumers' factors, as their values are often subjectively judged by life insurance companies and it is easy to manipulate for authorities. ${ }^{12} \mathrm{EV}$ focuses more on companies' internal conditions and less related to market and consumers' factors as goodwill is not taken into consideration.

\section{Local accounting standards in Taiwan and IFRS 4 Phase 1}

IFRS 4 Phase I insurance contracts was issued by the IASB on 31 March 2004 as the first step in the IASB's project to achieve convergence of widely varying insurance accounting practices around the world. Companies in Taiwan are required to adopt Phase I of IFRS4 starting from 2011. While the introduction of IFRS 4 Phase I (i.e., ROC GAAP No. 40) does not fully change Taiwan insurance accounting, many

\footnotetext{
${ }^{11}$ Appraisal Value equals to Embedded Value plus Goodwill.

12 See Campbell (2002).
} 
insurers in Taiwan therefore are afraid that the phase I of IFRS 4 would create big challenges. We summarise the main features of IFRS 4 Phase I (i.e., ROC GAAP No. 40) that are distinct from current insurance accounting in Taiwan.

\section{Catastrophe and equalisation provisions are prohibited}

Insurance accounting in Taiwan used to require the insurers to recognise the catastrophe provisions (i.e. a liability account) gradually over the years based on a prescribed formula and out of the premiums received. The provision can be used in the future when catastrophic losses caused by earthquake damages or some other disasters occur in the future. In addition, the insurance authority in Taiwan also requires insurers to make equalisation provisions to cover random fluctuations of claim expenses using a formula based on past experiences. However, IFRS 4 does not allow the recognition of both provisions as liability because they do not reflect loss events that have already occurred. Thus, in response to the prohibition by IFRS 4, the government would require insurers to reclassify the provisions from liability to equity. ${ }^{13}$

\section{Liability adequacy tests}

Paragraphs 15-19 of IFRS 4 require that all insurers assess at the end of each reporting period whether their recognised insurance liabilities are adequate, using current estimates of future cash flows of its insurance contracts. If the assessment shows that the carrying amount of its liabilities is inadequate, the entire deficiency shall be recognised as losses. An economic mismatch relates to the fact the companies are not able to match the timing of cash flows from insurance liabilities with the cash flows from the investments allocated to those liabilities. Asset-liability matching is a key driver of the profit or loss of an insurance company as the duration of the liabilities is often larger than that of the related assets. The fair value of liabilities would change by a larger amount than the fair value of assets when interest rate fluctuates, which in turn can create substantial volatility in net income and stockholders' equity. Taiwan's negative spread, the gap between the guaranteed interest rates on policies and the actual rate of return on investments (e.g. 1.48 per cent currently for government's treasury bonds) is the main reason that causes exodus of foreign insurers. The premiums for the in-force business for these contracts have been set to give a guaranteed minimum sum assured on death and a guaranteed surrender value on early surrender based on prevailing interest rate (e.g. 8 per cent) at the time of issuing policy. As market interest rates have reduced from 8 per cent when the policies were sold, to around 1.47 per cent currently, the rate of return on investments is falling below the guaranteed rate on policies, resulting in the worst negative spread against the majority of long-life insurance contracts in the world. ${ }^{14}$

\footnotetext{
13 See Chiu (2009).

${ }^{14}$ See Sun (2009) and Yang (2009).
} 


\section{Unbundling deposit component of insurance contracts}

IFRS 4 also requires that contracts be classified as either insurance contracts or investment contracts depending on the level of insurance risk transferred. An insurance contract is a contract under which the insurer accepts significant insurance risk from the policy-holder (the insured) by agreeing to compensate the policy-holder if a specified uncertain future insured event adversely affects the policy-holder. If the insured's significant insurance risk is transferred by the contract then it is classified as an insurance contract. Conversely, if contracts transfer financial risk but not significant insurance risk, they are termed investment contracts. This can include wealth management products such as savings, superannuation and allocated annuities where there is no insurance risk and no discretion over the vesting of policy-holder benefits (i.e., non-participating). Further, if an insurance contract contains both an insurance component and a deposit (investment) component, the deposit component must be treated as a financial liability or financial asset under IAS 39. As a result, the insurer would not recognize premium receipts for the deposit component as revenue. The insurance contracts are accounted for under IFRS 4 and the investment contracts are accounted for at fair value under IAS 39. For example, contracts with debt benefits linked to equity or equity index on death or annuitization are insurance contracts; but contracts with equity linked return available on surrender or maturity are investment contracts, which are measured at fair value under IAS 39.

Thus, insurers must first perform a product classification exercise across their portfolio of contracts. IFRS 4 permits the continued usage of previously applied GAAP for insurance contracts and investment contracts with discretionary participating features. For investment contracts that do not contain discretionary participating features, IAS 39 applies measurement principles to assets and liabilities attached to the contract.

\section{Insurance accounting measurement divergence and IFRS Phase II}

Life insurers across the globe prepare financial statements not only for shareholders, but also for the domestic insurance authority. Insurance authorities from many countries, including Taiwan, may require domestic insurers to adopt statutory accounting principles (SAP) instead of the GAAP for supervision purposes. For instance, for prudential regulation purpose, financial statements for U.K. life insurers were required. ${ }^{15}$

SAP generally is conservative as it usually yields lower capital for all insurers and lower income for growing insurers than what would be expected from compliance with the GAAP. The main reason is that insurance regulation focuses more on solvency and it is believed that high growth can harm solvency. ${ }^{16}$ For example, policy acquisition costs are expensed immediately under SAP, and asset valuation reserve or insurance liabilities are calculated using statutory assumptions that are generally conservative. Unrealised gains and losses on available-for-sale securities are not included in SAP

\footnotetext{
${ }^{15}$ See Klumpes et al. (2009).

${ }^{16}$ See Ryan (2007).
} 
capital and various illiquid assets are not admitted as assets under SAP. These examples illustrates how SAP yields lower capital in order to protect policy-holders, but the accounts prepared under this basis would understate the value of shareholders' equity and understate the reported profits. This would make the financial statements irrelevant to shareholders' decision-making.

To provide a better measure of life insurer's financial position from the shareholders' perspective, many countries have developed GAAP for insurance contracts. However, the GAAP on insurance contracts has been divergent across the globe. ${ }^{15}$ The main differences lie on: (a) the expensing or capitalisation of acquisition costs; and, (b) the methods/measurement for insurance contracts. As IFRS 4 Phase I, currently in effect, only bring limited improvements to accounting for insurance contracts, FASB and IASB are jointly developing Phase 2 of IFRS 4 and expect to publish a final standard in 2010. The two boards are aimed at achieving a consistency of valuation across insurance firms in the world. They propose to provide a coherent principlesbased framework for the measurement of insurance contracts and for the presentation of income and expense resulting from these contracts. Insurance contracts are valued based on market-based assessments of expected risks and rewards arising from the acceptance of insurance risks. Thus, we believe that IFRS 4 Phase 2 can help create a consistent standard that assists investors' understanding of insurance firms' profitability and financial position.

\section{Hypothesis developments}

\section{Value relevance of $\mathrm{EV}$}

There have been concerns that fair values are too noisy for financial reporting, as it is difficult to measure reliably fair values, and including fair values can make the assessment too unreliable. ${ }^{17}$ Using book values as the benchmark can limit incremental information value to items included in financial statements and does not hold fair values to the higher standard of being incremental to all information available to investors. We tests the value relevance of the EV approach because prior study suggests that value relevance is a better approach to test financial reporting research questions. ${ }^{18}$ Investors are primarily interested in information that can help them assess the value of the firm for purposes of making informed investment decisions. Valuation is a key input to and a key output of investors' decisions.

\section{Book value of shareholders' equity}

Specifically, insurance accounting has long been regarded as a black box for investors because financial statements from the insurance industry have generally not provided information of an appropriate nature to enable users of financial statements to readily

\footnotetext{
${ }^{17}$ See Barth (1994) and Barth et al. (1996).

${ }^{18}$ See Barth (2000).
} 
identify the drivers of the value in the business. ${ }^{19}$ The products underlying the insurance operations that are reflected in financial statements are inherently complex. Many industry executives thus believe that investors apply an accounting discount when valuing insurance business. Besides, local regulatory requirements are varied across countries, such that the industry practice of aggregating insurance liabilities can be measured in different ways. In particular, the accounting mismatch is a commonly observed problem for insurance accounting, where accounting practices do not reflect the economic basis on which insurance assets and liabilities are usually managed. For instance, in Taiwan, a substantial amount of the regulation for life insurers is directed towards ensuring capital adequacy rather than to provide information content for investors. Large insurance liabilities are measured at costs, while the related investments are measured at fair values. One way that IFRS 4 Phase 2 proposes to mitigate the effect of this asset-liability mismatch is to re-measure some insurance contracts at current interest rates and to use shadow accounting.

Thus, anecdotal evidence indicates that non-GAAP sources of information such as EV reports are more informative than GAAP-based financial statements.

\section{Embedded value}

Prior studies suggest that EV disclosures are value-relevant and have better explanatory ability for the shareholders' value, and CEOs of life insurance companies use EV as the basis for strategic management. ${ }^{20}$ Analysts think EV could make companies long-term oriented, evaluate internal performance effectively and provide more accurate and transparent financial reports to the public. If EV is based on longterm perspective, it could make it easier for managers to allocate resources and capital more efficiently by disposing unprofitable product lines and focusing on value-added products.

The main difference between EV and BV under traditional insurance accounting lies on the timing of recognition. The complications in assessing the value and performance of the contract lie in the uncertainties about mortality estimates, investment returns by life insurers and the termination risk by each policy-holder. Given the total recognised profit over the life of insurers is constant, traditional insurance accounting tends to defer future profits to the period when receiving future premiums; whereas under EV method, future profits are immediately recognised when signing new contracts. Thus, EV is more useful when investigating the change in firm value during different time periods. Investors can then discern the portions of profits that come from new business and the portions of profits from existing business. EV therefore can enhance the transparency of financial reports and improve the communication between companies and shareholders. In this study, we first examine the value relevance of EV. Further, we assess whether the share price explains EV, incremental to book values. If so, this suggests that fair values (EV) add to the relevance of amounts currently recognised in financial statements and that the fair value estimates reliably measure value reflected in the share price.

\footnotetext{
${ }^{19}$ See Meyer (2005).

${ }^{20}$ See Klumpes (2005); Horton (2007); Graham et al. (2003); and Mueller (2003).
} 
Thus, our first hypothesis is as follows:

H1: EV is value relevant for insurance firms.

H1a: The portion of additional retained profits (ARP) in the EV can provide incremental information for insurance firms, in addition to BV.

\section{Compare value relevance for insurers in Taiwan and in the $E U$}

One main difference between current statutory solvency rules in Taiwan and IFRS 4 Phase I arises from the liability adequacy test. IFRS 4 requires that the cash flows considered in a liability adequacy test should include the effect of embedded options and guaranteed annuity rates. Failing to include these guaranteed rates in determining the liability adequacy test might result in underestimation of the liability, in particular when the negative spread in Taiwan is the worst in Asia. ${ }^{21}$ Under current practice in Taiwan, the policy liabilities are calculated on sets of assumptions, which are locked in at the point of policy inceptions, and the insurance reserve provisioning is based on initial investment return assumption. This means that current interest rates need not be reflected and the regulatory capital regime is more lenient in addressing the interest rate risks facing life insurers. However, under IFRS 4 Phase I, the adequacy of the insurance contract liabilities is tested by reference to best estimates of expected investment returns on policy cash flows and reinvestment income. For example, the products of high-guaranteed rates issued by ING Co. during the era of high interest rates have significantly increased the fair value of liabilities and reduced the companies' economic capital required under the most stringent solvency standards ${ }^{22}$ and IFRS 4 . This in turn creates great losses and demands to strengthen reserves when the market interest has plunged to 1 or 2 per cent. Thus, these regulatory gaps have emboldened Taiwan local insurers to gamble on the European policies, aiming to grab more market share.

As the size of exposures to embedded guarantees in Taiwan is rather substantial and Taiwan's negative spread is quite large, we can expect that the BV in Taiwan is thus less relevant than that in EU if local practices in Taiwan fail to include these in the liability adequacy test. On the contrary, as insurers in the EU need to apply IFRS 4 Phase I to prepare the financial statements, the value relevance of financial reporting in the EU should be much higher than that in Taiwan. The test of this hypothesis will help understand whether IFRS provides more relevant information to investors. Thus, our second hypothesis is as follows:

H2: The value relevance of book value for insurers in Taiwan is much lower than that for insurers in the EU.

\footnotetext{
${ }^{21}$ See Sun (2009).

${ }^{22}$ European companies need to adhere to the European Union Insurance Group Directive ("IGD").
} 


\section{Research design}

\section{Value relevance of in-force long-term insurance contracts}

To test whether the EV is useful in equity valuation for life insurance companies, we use the level specification of the valuation model. Following prior literature, we use Ohlson's model to test whether the firm value is a function of the BV and net income, along with the unrecognised portion of assets and liabilities. ${ }^{23}$ The model has also been frequently used to test the value relevance of accounting information, together with any other value-relevant information as it forms a framework for understanding the relation between prices and accounting information. ${ }^{24}$

$$
\begin{aligned}
M V_{i t}= & \alpha_{0}+\alpha_{1} E V_{i t}+\alpha_{2} N I_{i t}+\varepsilon_{i t} \\
= & \alpha_{0}+\left(\alpha_{1} B V_{i t}+\alpha_{2} A R P_{i t}\right) \\
& +\alpha_{3} N I_{i t}+\varepsilon_{i t}
\end{aligned}
$$

where $M V_{i t}$ is the market value of equity for firm $i$ at time $t ; E V_{i t}$ is the EV of shareholders' equity for firm $i$ at time $t$, which equals to the sum of $B V_{i t}$ and $A R P_{i t}$; $B V_{i t}$ is the BV for firm $i$ at time $t$ under current GAAP and statutory solvency basis; $A R P_{i t}$ is the additional present value of the in-force long-term assets, which is the portion of $E V_{i t}$ that is not incorporated in the balance sheet; $N I_{i t}$ is net income for firm $i$ at time $t$ under current GAAP and statutory solvency basis. We use per share data in our cross-sectional levels models and conduct the sensitivity analyses with different deflators. $^{25}$

Under the EV principle, the EV of shareholders' equity $\left(E V_{i t}\right)$ includes the net worth based on statutory solvency basis $\left(B V_{i t}\right)$, and the value of future cash flows expected to arise from the current book of long-term insurance business $\left(A R P_{i t}\right)$. Thus, we further decompose $\mathrm{EV}_{i t}$ into $\mathrm{BV}_{i t}$ and $\mathrm{ARP}_{i t}$ in Eq. (1a) to allow the coefficients on the element of EV that is incorporated in the balance sheet and the element of EV that will be recognised in the balance sheet to vary. As ARP can reflect the present value of inforce long-term business in the future, we expect that ARP can provide an additional information role for stock valuation. A significantly positive coefficient on ARP would provide evidence consistent with the combined relevance and reliability of the EV disclosed by each firm.

${ }^{23}$ See Ahmed and Takeda (1995); Barth et al. (1996); Venkatachalam (1996); Collins et al. (1997); Collins et al. (1999); and Aboody and Lev (1998).

${ }^{24}$ Demers (1997) utilises the Feltham and Ohlson (1995) methodology to examine the value-relevance of earnings and book value for U.S. property-casualty insurance companies. Ohlson (1995) assumes that the evolution of accounting earnings is unaffected by biases induced by conservatism (or aggressive accounting) that would result in understated (overstated) book value of equity. Feltham and Ohlson $(1995,1996)$ lift the restrictions and add the "conservatism" element in the valuation model. Our tests based on Ohlson (1995) can be subject to this limitation. For robustness tests, we employ the same approach as Demers (1997) that is based on Feltham and Ohlson (1996). Our results are qualitative similar and do not affect our interpretation of the findings.

${ }^{25}$ See Barth et al. (1996). 
In addition, different from Taiwanese insurers, the insurers in the EU disclose not only the EV of shareholders' funds $\left(E V_{i t}\right)$, and also the achieved profits for the life insurance business under embedded value $\left(E V_{-} N I_{i t}\right)$, we also include $E V V_{-} N I_{i t}$ as an additional independent variable to test whether it can provide incremental information content.

$$
\begin{aligned}
M V_{i t}= & \alpha_{0}+\alpha_{1} B V_{i t}+\alpha_{2} A R P_{i t}+\alpha_{3} N I_{i t} \\
& +\alpha_{4} E V_{-} N I_{i t}+\varepsilon_{i t}
\end{aligned}
$$

If $E V$ accounting $\left(E V_{i t} ; E V \_N I_{i t}\right)$ can provide value relevance on top of the book value $\left(B V_{i t}\right)$ and net income reported on current GAAP and the statutory solvency basis $\left(N I_{i t}\right)$, we would expect that $\alpha_{2}$ and $\alpha_{4}$ should be positively signed and significantly different from zero.

\section{Compare value relevance for insurers in Taiwan in the EU}

To test our Hypothesis 2 whether the value relevance of book value of shareholders' funds is higher for the insurers in the EU under IFRS scheme than insurers in Taiwan under ROC GAAP, we employ two approaches. Following prior literature ${ }^{26}$ that compares the value relevance of accounting information across different countries, we pool the sample from Taiwan and the EU, and insert an indicator variable $\left(D U M_{i t}\right)$ to interact with all accounting variables in Eq. (2). $D U M_{i t}$ equals to 1 when observations are from insurers in Taiwan and zero when observations are from insurers in EU.

$$
\begin{aligned}
M V_{i t}= & \alpha_{0}+\alpha_{1} B V_{i t}+\alpha_{2} A R P_{i t}+\alpha_{3} N I_{i t} \\
& +\alpha_{4} D U M_{i t}+\alpha_{5} D U M_{i t} \times B V_{i t} \\
& +\alpha_{6} D U M_{i t} \times A R P_{i t}+\alpha_{7} D U M_{i t} \\
& \times N I_{i t}+\text { Country }+ \text { Year }
\end{aligned}
$$

To test for Hypothesis 2, our focus of regression (2) is on $\alpha_{5}$, which is the coefficient for value relevance of $\mathrm{BV}$ for insurers in Taiwan relative to insurers in the EU. We expect significant negative values for $\alpha_{5}$ if Hypothesis 2 is supported. Specifically, if accounting quality for insurers under IFRS scheme is much higher than local GAAP in Taiwan, we expect that balance sheet of the EU sample can capture economic performance more fully than that of the sample in Taiwan. To the extent that the stock price can fully reflect economic performances, we expect that the value relevance of BV is lower for Taiwanese insurers than the EU counterparts.

Testing whether the interaction term between $D U M_{i t}$ and $B V_{i t}$ is significantly negative is the same as using the chow test ( $\mathrm{F}$ test) to examine whether the coefficient on $B V_{i t}$ of Eq. (1a) is lower for Taiwanese insurers than for the insurers from the EU. Following prior studies, ${ }^{26}$ we control for country effects to ensure that the characteristics of the sample might differ across countries. We also control for the

\footnotetext{
${ }^{26}$ See Ball et al. (2000) and Ball et al. (2003).
} 
year effects such as period-specific economic effects that are not captured by the explanatory variables.

\section{Empirical results}

\section{Sample and descriptive statistics}

The sample for this study consists of life insurance companies listed on the Taiwan Stock Exchange and insurance companies listed on the London Stock Exchange and the Euronext exchanges during 2005 and 2008. We do not include in our sample if the insurance companies do not disclose EV. Because of the limited number of life insurance firms in Taiwan, we use quarterly data to test for the sample in Taiwan. The EV disclosure for Taiwanese firms is collected from companies' investor conference reports, and the accounting information is from the Taiwan Economics Journal (TEJ) database. For the EU sample, following prior study, ${ }^{27}$ we manually collect the accounting numbers, the embedded values $\left(E V_{i t}\right)$ and the achieved profits under embedded value $\left(E V \_N I_{i t}\right)$ from the firm's own annual reports as these values are not separately reported in any database. All the variables are in U.S. dollars.

Table 2 presents descriptive statistics for the $B V_{i t}, A R P_{i t}$ and $N I_{i t}$ of our sample. Panel A of Table 2 reports the statistics for the whole sample, Panel B reports the statistics for Taiwanese sample and Panel $\mathrm{C}$ reports the statistics for the EU sample. All panels reveal that the mean of stock price exceeds the book value of net assets, indicating the presence of unrecognised assets. In Panel $\mathrm{B}$, the mean of $A R P_{i t}$, the offbalance sheet items, is 0.421 in Taiwan, about three quarters of the book value of net assets $\left(B V_{i t}\right)$. This suggests that the present value of internally generated in-force longterm contracts (i.e. the element bypassing the balance sheet) is substantial relative to the BV under the statutory solvency basis. The pattern is the same in Panel $\mathrm{C}$ when we examine the EU sample. The extent to which $A R P_{i t}$ can help explain cross-sectional variation in market-to-book differences in equity is examined in the next section.

Table 3 shows the correlation between stock price and independent variables used in the regressions. We find that stock price $\left(\right.$ Price $\left._{i t}\right)$ significantly correlates with $\mathrm{BV}$ $\left(B V_{i t}\right)$, net income $\left(B V_{i t}\right), A R P_{i t}$, total assets $\left(\right.$ Asset $\left._{i t}\right)$ and total liabilities $\left(\right.$ Liability $\left._{i t}\right)$ under Spearman and Pearson correlation test for the sample in Taiwan. In Panel B, the results are qualitatively similar. $\mathrm{BV}_{i t}$ and $\mathrm{ARP}_{i t}$ are associated with stock price at a 1 per cent significance level. When considering net income under the EV method $\left(E V_{-} N I_{i t}\right)$, we also find a positive association between Price $_{i t}$ and $E V_{-} N I_{i t}$.

\section{Value relevance of in-force long-term insurance contracts in Taiwan}

Table 4 reports the results of the tests on Hypothesis 1, to see whether $E V_{i t}$ is value relevant and whether $A R P_{i t}$ can provide an additional role for stock valuations. Table 4 reports the results. Column 1 of Table 4 reports the coefficient on book value and net income, and column 2 separates the BV into total assets and liabilities to allow

\footnotetext{
${ }^{27}$ See Horton (2007).
} 
Table 2 Descriptive statistics

\begin{tabular}{|c|c|c|c|c|c|}
\hline Variable & Mean & Std Dev & $P 25$ & $P 50$ & P75 \\
\hline \multicolumn{6}{|c|}{ Panel A: Whole sample } \\
\hline Price & 22.273 & 48.788 & 0.929 & 2.1 & 23.72 \\
\hline$B V$ & 20.164 & 44.726 & 0.649 & 1.514 & 17.744 \\
\hline$A R P$ & 8.823 & 19.319 & 0.362 & 0.768 & 8.221 \\
\hline$N I$ & 1.706 & 5.197 & 0.019 & 0.061 & 0.456 \\
\hline \multicolumn{6}{|c|}{ Panel B: Taiwan sample } \\
\hline Price & 1.106 & 0.659 & 0.592 & 0.919 & 1.313 \\
\hline$B V$ & 0.57 & 0.183 & 0.397 & 0.624 & 0.717 \\
\hline Asset & 9.594 & 2.178 & 7.579 & 9.934 & 11.681 \\
\hline Liability & 9.025 & 2.086 & 6.927 & 9.44 & 10.954 \\
\hline$A R P$ & 0.421 & 0.251 & 0.224 & 0.361 & 0.682 \\
\hline$N I$ & 0.031 & 0.039 & 0.015 & 0.034 & 0.053 \\
\hline \multicolumn{6}{|c|}{ Panel $C:$ EU sample } \\
\hline Price & 38.35 & 60.038 & 2.463 & 20.49 & 34.19 \\
\hline$B V$ & 35.045 & 54.95 & 1.947 & 16.157 & 35.625 \\
\hline$A R P$ & 15.203 & 23.765 & 1.004 & 7.36 & 19.725 \\
\hline$N I$ & 3.326 & 6.938 & 0.115 & 0.436 & 3.408 \\
\hline$E V \_N I$ & 2.267 & 13.082 & 0.132 & 0.476 & 1.571 \\
\hline
\end{tabular}

Note: Data includes all insurance firms in Taiwan and in EU during 2004-2008. All variables are in U.S. dollars. Price denotes the stock price; $B V$ denotes book value of stockholders' equity per share; $N I$ denotes net income per share; $A R P$ denotes the element of embedded value that bypasses the balance sheet per share (i.e., the value of in-force assets); Asset denotes total assets of consolidated statements for firm I per share; Liabilities denotes total liabilities of consolidated statements for firm $i$ per share; $E V \_N I$ denotes net income from embedded value per share. All regression variables are deflated by the number of shares outstanding at year-end.

their coefficients to vary. If markets are perfect and complete and if the reported book value of assets and liabilities can measure market value of shareholders' equity without errors, the coefficients for the assets and liabilities should be significant. Column 3 (4) is based on the same regression as column 1 (2), except that column 3 (4) include $A R P_{i t}$ as an additional variable.

Column 1 first shows that the estimated coefficient on $B V_{i t}$ is significantly positive (coefficient $=2.094, t=8.02$ ). In contrast, the coefficient on net income is positive and insignificant. Income statement might not be relevant for economic earnings because of the mismatch in the recognition of revenue and costs for long-term contracts in insurance firms.

After we add $A R P_{i t}$ into the model, the explanatory power increases from 53 per cent in column 1 to 77 per cent in column 3. The estimated coefficient for $A R P_{i t}$ is 3.131 in column 3 and statistically different from zero. This also supports our Hypothesis 1a that $A R P_{i t}$ is value relevant for insurance companies. When we separate $B V_{i t}$ into Asset $_{i t}$ and Liability $_{i t}$, column 2 and 4 shows consistent results that both Asset $_{i t}$ and Liability $_{i t}$ are significant, and $A R P_{i t}$ can play an important role in assessing equity value. 
Table 3 Correlation table

Panel A: Taiwan sample

\begin{tabular}{lcccccc}
\hline & Price & $B V$ & $N I$ & ARP & Asset & Liability \\
\hline Price & 1.000 & 0.840 & 0.330 & 0.584 & 0.714 & 0.684 \\
& & $(0.000)$ & $(0.010)$ & $(0.000)$ & $(0.000)$ & $(0.000)$ \\
$B V$ & 0.736 & 1.000 & 0.348 & 0.338 & 0.484 & 0.440 \\
& $(0.000)$ & & $(0.007)$ & $(0.008)$ & $(0.000)$ & $(0.000)$ \\
$N I$ & 0.318 & 0.350 & 1.000 & 0.225 & 0.290 & 0.278 \\
& $(0.013)$ & $(0.006)$ & & $(0.085)$ & $(0.025)$ & $(0.032)$ \\
ARP & 0.685 & 0.296 & 0.271 & 1.000 & 0.746 & 0.746 \\
& $(0.000)$ & $(0.022)$ & $(0.036)$ & & $(0.000)$ & $(0.000)$ \\
Asset & 0.710 & 0.533 & 0.204 & 0.675 & 1.000 & 0.997 \\
& $(0.000)$ & $(0.000)$ & $(0.118)$ & $(0.000)$ & & $(0.000)$ \\
Liability & 0.677 & 0.468 & 0.183 & 0.679 & 0.997 & 1.000 \\
& $(0.000)$ & $(0.000)$ & $(0.162)$ & $(0.000)$ & $(0.000)$ & \\
\hline
\end{tabular}

Panel B: EU sample

\begin{tabular}{lccccc}
\hline & Price & $B V$ & ARP & NI & $E V_{-} N I$ \\
\hline Price & 1.000 & 0.885 & 0.823 & 0.784 & 0.722 \\
& & $(0.000)$ & $(0.000)$ & $(0.000)$ & $(0.000)$ \\
$B V$ & 0.950 & 1.000 & 0.886 & 0.644 & 0.531 \\
& $(0.000)$ & & $(0.000)$ & $(0.000)$ & $(0.000)$ \\
$A R P$ & 0.912 & 0.922 & 1.000 & 0.610 & 0.593 \\
& $(0.000)$ & $(0.000)$ & & $(0.000)$ & $(0.000)$ \\
$N I$ & 0.963 & 0.912 & 0.892 & 1.000 & 0.803 \\
& $(0.000)$ & $(0.000)$ & $(0.000)$ & & $(0.000)$ \\
$E V \_N I$ & 0.742 & 0.544 & 0.686 & 0.758 & 1.000 \\
& $(0.000)$ & $(0.000)$ & $(0.000)$ & $(0.000)$ & \\
\hline
\end{tabular}

Note: Data includes all insurance firms in Taiwan and in EU during 2004-2008. All variables are in U.S. dollars. Price denotes the stock price; $B V$ denotes book value of stockholders' equity per share; $N I$ denotes net income per share; $A R P$ denotes the element of embedded value that bypasses the balance sheet per share (i.e., the value of in-force assets); Asset denotes total assets of consolidated statements for firm I per share; Liabilities denotes total liabilities of consolidated statements for firm $i$ per share; $E V \_N I$ denotes net income from embedded value per share. All regression variables are deflated by the number of shares outstanding at year-end.

\section{Value relevance of in-force long-term insurance contracts in the EU}

Regression results for tests of value-relevance of $A R P_{i t}$ and $E V \_N I_{i t}$ for the EU sample are reported in Table 5. Four versions are estimated: (1) including $B V_{i t}$ and $N I_{i t}$ reported under statutory solvency basis in column 1; (2) adding $A R P_{i t}$, along with $B V_{i t}$ and $N I_{i t}$ in column 2; (3) adding $E V \_N I_{i t}$, along with $B V_{i t}$ and $N I_{i t}$ in column 3; (4) and adding both $A R P_{i t}$ and $E V \_N I_{i t}$, along with $B V_{i t}$ and $N I_{i t}$ in column 4 . In all versions, the coefficients on $B V_{i t}$ and $N I_{i t}$ are positive and statistically significant suggesting that both balance sheet and income statement are useful in equity valuation. Results from column 2 and 4 reveal that the coefficients on $A R P_{i t}$ are significantly different from zero, suggesting that $A R P_{i t}$ provide incremental value-relevant information to $B V_{i t}$ in 
Table 4 Value relevance of accounting information for the Taiwan sample

\begin{tabular}{|c|c|c|c|c|}
\hline & (1) & (2) & (3) & (4) \\
\hline & Price & Price & Eq. (1a) Price & Price \\
\hline Intercept & $\begin{array}{l}-10.608 \\
(-2.94)^{* *}\end{array}$ & $\begin{array}{l}-32.216 \\
(-5.37)^{* * *}\end{array}$ & $\begin{array}{l}-18.172 \\
(-5.05)^{* * *}\end{array}$ & $\begin{array}{l}-22.839 \\
(-3.76)^{* * *}\end{array}$ \\
\hline$B V$ & $\begin{array}{l}2.094 \\
(8.02)^{* * *}\end{array}$ & & $\begin{array}{c}0.820 \\
(10.28)^{* * *}\end{array}$ & \\
\hline Asset & & $\begin{array}{c}1.905 \\
(10.55)^{* * *}\end{array}$ & & $\begin{array}{l}1.924 \\
(9.00)^{* * *}\end{array}$ \\
\hline Liability & & $\begin{array}{l}-1.226 \\
(-9.88)^{* * *}\end{array}$ & & $\begin{array}{l}-1.919 \\
(-8.08)^{* * * *}\end{array}$ \\
\hline$N I$ & $\begin{array}{r}6.233 \\
(0.72)\end{array}$ & $\begin{array}{r}5.940 \\
(0.82)\end{array}$ & $\begin{array}{c}-1.973 \\
(-0.50)\end{array}$ & $\begin{array}{l}-2.315 \\
(-0.22)\end{array}$ \\
\hline$A R P$ & & & $\begin{array}{l}3.131 \\
(7.94)^{* * *}\end{array}$ & $\begin{array}{l}3.306 \\
(4.06)^{* * *}\end{array}$ \\
\hline Control for year & Yes & Yes & Yes & Yes \\
\hline$N$ & 60 & 60 & 60 & 60 \\
\hline Adj. $R^{2}$ & 0.530 & 0.669 & 0.770 & 0.774 \\
\hline
\end{tabular}

Note: Regression model (1a) is estimated using pooled cross-section and time-series data for insurance firms in Taiwan during 2005-2008. Price denotes the stock price; $B V$ denotes book value of stockholders' equity; $N I$ denotes net income; $A R P$ denotes the element of embedded value that bypasses the balance sheet (i.e., the value of in-force assets); Asset denotes total assets of consolidated statements for firm i; Liabilities denotes total liabilities of consolidated statements for firm $i$; All regression variables are deflated by the number of shares outstanding at year-end. $t$-statistics are given in parentheses and are adjusted for heteroscedasticity. *** and **denote significance at the 1 per cent, and 5 per cent levels, respectively, in a two-tailed test.

equity valuation. The coefficient on $E V \_N I_{i t}$ in column 3 and 4 are also positive and significant, consistent with prior studies. To summarise, Table 5 indicates the importance to provide EV estimate for long-term insurance contracts and associated profits under EV methodology.

\section{Comparisons between Taiwan and the EU}

For insurers in the EU, 2005 was the first year of reporting under IFRS. If the introduction of IFRS can help clarify the complexity inherent in insurance accounting, we expect that the value relevance of BV under IFRS regime in the EU would be much higher than that under local solvency standards in Taiwan. To test Hypothesis 2, to know whether BV under insurance accounting in Taiwan is less value-relevant than that for European insurers under European solvency standards and IFRS 4, we use two approaches. First, we conduct the Chow test to compare coefficients of $B V_{i t}$ in Eq. (1) for the Taiwan sample and the EU sample. Untabulated results show that $F$ value is 33 for BV, which suggests that BV is significantly higher for the EU sample than for the Taiwan sample.

Second, we divide the whole sample into the EU sample and the Taiwan sample and create an indicator $D U M_{i t}(=1$ for Taiwan and 0 for EU). We estimate Eq. (2) and 
Table 5 Value relevance of accounting information for the EU sample

\begin{tabular}{|c|c|c|c|c|}
\hline & \multirow{2}{*}{$\frac{(1)}{\text { Price }}$} & (2) & (3) & (4) \\
\hline & & Eq. (1a) Price & Price & Eq. (1b) Price \\
\hline \multirow[t]{2}{*}{ Intercept } & 6.723 & 12.283 & 7.892 & 4.123 \\
\hline & $(0.54)$ & $(0.55)$ & $(3.33)^{* * *}$ & $(3.45)^{* * *}$ \\
\hline \multirow[t]{2}{*}{$B V$} & 3.750 & 3.423 & 2.072 & 2.910 \\
\hline & $(6.91)^{* * *}$ & $(5.43)^{* * *}$ & $(18.84)^{* * *}$ & $(10.85)^{* * *}$ \\
\hline \multirow[t]{2}{*}{$N I$} & 4.653 & 6.781 & & 1.891 \\
\hline & $(5.63)^{* * *}$ & $(11.23)^{* * *}$ & & $(2.40)^{* *}$ \\
\hline \multirow[t]{2}{*}{$A R P$} & & 1.926 & 3.434 & 2.138 \\
\hline & & $(3.36)^{* * *}$ & $(9.34)^{* * *}$ & $(8.22)^{* * *}$ \\
\hline \multirow[t]{2}{*}{$E V_{-} N I$} & & & 2.351 & 4.531 \\
\hline & & & $(11.47)^{* * *}$ & $(9.53)^{* * *}$ \\
\hline Control for country & Yes & Yes & Yes & Yes \\
\hline Control for year & Yes & Yes & Yes & Yes \\
\hline$N$ & 62 & 62 & 62 & 62 \\
\hline Adj. $R^{2}$ & 0.70 & 0.790 & 0.898 & 0.979 \\
\hline
\end{tabular}

Note: Regression models (1a) and (1b) are estimated using pooled cross-section and time-series data for insurance firms in EU during 2005 to 2008. Price denotes the stock price; $B V$ denotes book value of stockholders' equity; NI denotes net income; $A R P$ denotes the element of embedded value that bypasses the balance sheet (i.e., the value of in-force assets); $E V \_N I$ denotes net income from embedded value. All regression variables are deflated by the number of shares outstanding at year-end. t-statistics are given in parentheses and are adjusted for heteroscedasticity. ${ }^{* *}, * *$ and $*$ denote significance at the 1 per cent, 5 per cent and 10 per cent levels, respectively, in a two-tailed test.

Table 6 reports the results. The main parameter of interest, $D U M_{i t} \times B V_{i t}$ is the interaction terms that measure the difference between the sample from Taiwan and the EU in terms of the relation between price and book value of net assets. The coefficient on $D U M_{i t} \times B V_{i t}$ is $-0.958(t=-3.39)$. The results show that book value of net assets for the sample in Taiwan is less associated with share price than that for the sample in the EU, supporting Hypothesis 2.

\section{Conclusions and discussion}

In this study, we examine the value relevance of financial statements for life insurers, with particular interest in the EV disclosure. It has long been a criticism that traditional accounting in Taiwan's insurance industry generates distorted value-added signals, as it ignores the future from existing contracts. As profits are deferred to the period when premium is received, but expenditures are charged when they are incurred in the first year, clearly it can cause a big "mismatch" between economic profits and accounting profits for each period. Thus, more and more life-insurance companies are using the EV model to evaluate performance.

Our sample includes the insurers in Taiwan and in the EU. Using the Ohlson valuation model, we examined whether the EV which is not yet reported on the balance sheet has an incremental role for stock valuation, in addition to the element 
Table 6 Value relevance of accounting information for the whole sample and the Taiwanese sample

\begin{tabular}{lc}
\hline Eq. (2) & Price \\
\hline Intercept & 4.219 \\
$B V$ & $(2.03)^{*}$ \\
& 1.445 \\
$A R P$ & $(5.12)^{* * *}$ \\
$N I$ & 1.038 \\
& $(6.27)^{* * *}$ \\
$D U M$ & 4.428 \\
& $(34.59)^{* * *}$ \\
$D U M^{*} B V$ & 7.164 \\
$D U M^{*} A R P$ & $(0.82)$ \\
$D U M^{*} N I$ & -0.958 \\
Control for country & $(-3.39)^{*}$ \\
Control for year & -0.567 \\
$N$ & $(-2.56)^{*}$ \\
$A d j . R^{2}$ & -3.256 \\
$N o t \rho^{*}$ & $(-2.50)^{*}$ \\
YES & YES
\end{tabular}

Note:

$$
\begin{aligned}
M V_{i t}= & \alpha_{0}+\alpha_{1} B V_{i t}+\alpha_{2} A R P_{i t}+\alpha_{3} N I_{i t} \\
& +\alpha_{4} D U M_{i t}+\alpha_{5} D U M_{i t} \times B V_{i t} \\
& +\alpha_{6} D U M_{i t} \times A R P_{i t}+\alpha_{7} D U M_{i t} \\
& \times N I_{i t}+\text { Country }+ \text { Year }
\end{aligned}
$$

Regression model (2) is estimated using pooled cross-section and time-series data for insurance firms in Taiwan and in EU during 2004 to 2008. Price denotes the stock price; $B V$ denotes book value of stockholders' equity; NI denotes net income; $A R P$ denotes the element of embedded value that bypasses the balance sheet (i.e., the value of in-force assets); $D U M$ equals to 1 if the observation is from Taiwan and 0 if it is from EU. All regression variables are deflated by the number of shares outstanding at year-end. $\mathrm{t}$-statistics are given in parentheses and are adjusted for heteroscedasticity. $* * *, * * a n d *$ denote significance at the 1 per cent, 5 per cent and 10 per cent levels, respectively, in a two-tailed test.

that has been taken into account in the books. Our results find that EV is value relevant in Taiwan and in the EU, and ARP plays an important role in stock valuation. Finally, to provide some implications for the recent departures of EU insurers from Taiwan, we compare the value relevance of the book value in Taiwan and in the EU. We find that the BV in the EU sample is much higher than that in Taiwan. This seems to suggest that the introduction of IFRS helped clarify the complexity inherent to insurance accounting and enhanced the financial information quality.

Our contributions include two parts. First, as IFRS 4 Phase 2 requires fair value measurement of all contractual cash flows on assets and liabilities, many insurance companies are concerned with serious capital inadequacy. The EV model is a concept approaching the fair value model, and our study can provide important evidence 
supporting IFRS 4. Second, our evidence can provide implications to policy-makers that leveling a playing field similar to other countries is extremely important to avoid the regulation arbitrage. As the Financial Services Commission in Taiwan has decided that all insurers in Taiwan are required to adopt IFRS 4 specifically from 2011 onwards, and full adoption of all IFRS standards from 2013 onwards, the adoption of IFRS 4 for insurers in Taiwan can involve a radical change for insurance firms, which in turn might cause severe capital inadequacy. Thus, the government in Taiwan and insurers in Taiwan need to take a couple of steps to tackle the forthcoming challenges.

We offer some suggestions. First, in order to present a coherent and credible picture to the financial markets, regulatory authorities and insurers need to work together to ensure the consistency between the IFRS 4 and the local regulatory requirements. Although IFRS and regulatory reporting serve fundamentally different purposes, the two are becoming increasingly aligned as supervisors and the IASB look to enhance the synergies and reduce potential duplication. Substantial adjustments may be necessary to ensure compliance with both sets of requirements. Second, the board of directors of each insurer needs to develop a plan to increase the reserve adequacy. Some insurers in Taiwan are beginning to sell some real estate or to plan another seasoned equity issue (SEO). The government can also help the insurers build up the capital adequacy in due course. Third, because of the sustained low interest rate environment in Taiwan, insurers should reduce the further development of insurance products with interest-rate guarantees embedded in the life and health contracts. The launch of the long-term interest-rate life contracts that guarantee 6-8 per cent interests before 2001 is the main source of the capital inadequacy in the insurance industry.

Finally, other capital market metrics, such as cost of capital or trading volume, can also be used to provide insights into the role of disclosed accounting information. As our focus is on the firms that disclose $\mathrm{EV}$, this requirement restricts the sample size, which in turn limits our extension to work on the cost of capital perspective. Future research can examine whether the disclosure of EV can help reduce the cost of capital incremental to the BV.

\section{Acknowledgements}

The authors gratefully acknowledge the helpful comments of the editor, referees, and seminar participants.

\section{References}

Aboody, D. and Lev, B. (1998) 'The value-relevance of intangibles: The case of software capitalization', Journal of Accounting Research 36(supplement): 161-191.

Ahmed, A.S. and Takeda, C. (1995) 'Stock market valuation of gains and losses on commercial banks' investment securities: An empirical analysis', Journal of Accounting and Economics 20: 207-225.

Babbel, D.F. and Merrill, C. (1998) 'Economic valuation models for insurers', North American Actuarial Journal 2(3): 1-17.

Babbel, D.F. and Merrill, C. (1999) 'Toward a unified valuation model for life insurers', in J.D. Cummins and A.M. Santomero (eds.) Changes in the Life Insurance Industry: Efficiency, Technology and Risk Management, London: Kluwer Academic Publishers. 
Babbel, D.F. and Stricker, R. (1987) 'Asset/liability management for insurers', Insurance Perspectives, Goldman Sachs, May, pp. 1-26.

Ball, R., Kothari, S.P. and Robin, A. (2000) 'The effect of international institutional factors on properties of accounting earnings', Journal of Accounting and Economics 29(1): 1-51.

Ball, R., Robin, A. and Wu, J. (2003) 'Incentives versus standards: Properties of accounting income in four East Asian countries', Journal of Accounting and Economics 36(1-3): 235-270.

Barth, M.E. (1994) 'Fair value accounting: Evidence from investment securities and the market valuation of banks', The Accounting Review 69: 1-25.

Barth, M.E. (2000) 'Valuation-based accounting research: Implications for financial reporting and opportunities for future research', Accounting and Finance 40(1): 7-32.

Barth, M.E., Beaver, W.H. and Landsman, W.R. (1996) 'Value-relevance of banks' fair value disclosures under SFAS No. 107', The Accounting Review 71(4): 513-537.

CFO Forum (2004) 'European Embedded Value Principles and Basis for Conclusions', from http://www .cfoforum.nl/embedded_value.htm.

CFO Forum (2005) 'Additional Guidance European Embedded Value Disclosures', from http://www .cfoforum.nl/embedded_value.html.

CFO Forum (2008) 'Market Consistent Embedded Value (MCEV) Principles', from http://www.cfoforum.nl/ embedded value.html.

Campbell, C.B. (2002) Embedded value of life insurance product lines, Boston Annual Meeting.

Chen, Y.S. and Chang, H.Y. (2009) 'Taiwan's insurance industry left stranded', Common Wealth Magazine 417: $1-7$.

Chien, S.C. (2005) The Principle and Practice of Insurance Accounting, Taipei, MA: San-Ming Publisher.

Chiu, C.L. (2009) 'The provisions are not allowed to write back under GAAP No. 40', Economic Daily News, A13, 23 November.

Collins, D.W., Maydew, E.L. and Weiss, I.S. (1997) 'Changes in the value-relevance of earnings and book value over the past forty years', Journal of Accounting and Economics 24(1): 39-67.

Collins, D.W., Pincus, M. and Xie, H. (1999) 'Equity valuation and negative earnings: The role of book value of equity', The Accounting Review 74: 29-61.

Demers, E.A. (1997) Alternative valuation models and the valuation parameters of property-casualty insurers' share prices, working paper, Stanford University.

Duverne, D. and Le Douit, J. (2007) 'IFRS for insurance: CFO forum proposals', The Geneva Papers on Risk and Insurance Issues and Practice 32(1): 62-74.

Feltham, G.A. and Ohlson, J.A. (1995) 'Valuation and clean surplus accounting for operating and financial activities', Contemporary Accounting Research 11(2): 689-731.

Feltham, G.A. and Ohlson, J.A. (1996) 'Uncertainty resolution and the theory of depreciation measurement', Journal of Accounting Research 34(2): 209-234.

Graham, R.C., Lefanowicz, C.E. and Petroni, K.R. (2003) 'The value relevance of equity method fair value disclosures', Journal of Business Finance and Accounting 30: 1065-1088.

Horton, J. (2007) 'The value relevance of "realistic reporting": Evidence from U.K. life insurers', Accounting and Business Research 37(3): 175-179.

Hsu, W. (2010) 'Don't let new insurance accounting to scare away foreign insurers', United Daily News, A17, 27 March.

Klumpes, J.M. (2005) 'Managerial use of discounted cash-flow or accounting performance measures: Evidence from the U.K. life insurance industry', The Geneva Papers on Risk and Insurance Issues and Practices 30(1): 171-186.

Klumpes, J.M., O'Brien, C.D. and Reibel, A. (2009) 'International diversity in measuring the fair value of life insurance contracts', The Geneva Papers on Risk and Insurance Issues and Practices 34(2): 197-227.

Lee, S.H. (2009) 'Don't let competition decay as foreign insurers exists from Taiwan', Economic Daily News, A6, 10 October.

Meyer, L. (2005) 'Insurance and international financial reporting standards', The Geneva Papers on Risk and Insurance Issues and Practices 30(1): 114-120.

Mueller, H. (2003) 'Uncovering value', Best's Review 104(6): 61-65.

Ohlson, J. (1995) 'Earning, book values, and dividends in equity valuation', Contemporary Accounting Research 11(2): 661-687. 
Reitano, R. (1997) 'Two paradigms for the market value of liabilities', North American Actuarial Journal 1(4): 104-137.

Ryan, S.G. (2007) Financial Instruments and Institutions, New Jersey: John Wiley \& Sons, Inc.

Staking, K.B. and Babbel, D.F. (1995) 'The relation between capital structure, interest rate sensitivity, and market value in the property-liability insurance industry', Journal of Risk and Insurance 62(4): 690-718.

Sun, C.Y. (2009) 'The negative spread in the life insurance is the worst in the world', United Daily News, AA1, 26 November.

Venkatachalam, M. (1996) 'Value-relevance of banks' derivatives disclosures', Journal of Accounting and Economics 22(1-3): 327-355.

Yang, M.L. (2009) 'Why do foreign insurers leave Taiwan?' United Daily Evening News, A3, 25 November.

\section{About the Authors}

Rebecca Chung-Fern Wu is Professor of the Accounting Department at National Taiwan University. She received her PhD from the University of California, Los Angeles. Her area of research includes accounting and information issues in financial industries. Her research has appeared in scholarly journals such as Annals of Operations Research, Information \& Management, International Journal of Accounting Studies, Review of Securities and Futures Markets and The Empirical Economics Letters, etc.

Audrey Wen-Hsin Hsu is Assistant Professor of the Accounting Department at National Taiwan University. She received her PhD from Lancaster University, U.K. Her area of research includes financial reporting quality, international accounting standards, financial distress risk and capital market research. Her research has appeared in publications such as Asia Pacific Journal of Accounting and Economics, Service Industry Journal, European Company and Financial Law Review, Abacus, European Accounting Review, etc. 